\title{
Peaceful Proposals and Maritime Cooperation between Mainland China, Japan, and Taiwan in the East China Sea: Progress Made and Challenges Ahead
}

\author{
Yann-huei Song
}

\section{Introduction}

In the East China Sea, there exist two sets of peaceful proposals and two sets of agreements on maritime cooperation, both of which deal with the complicated maritime disputes and aim to help maintain peace and stability in this important body of water between the three parties, namely, China, ${ }^{1}$ Japan, and Taiwan. ${ }^{2}$ The first set of proposals refer to the peace initiatives that were announced by the Chinese and Japanese leaders after they met in Beijing and Tokyo, respectively, during the period of time between 2006 and 2008, ${ }^{3}$ and the East China Sea Peace Initiative (hereafter referred to as "ECSPI") proposed by Taiwan's President Ma Ying-Jiou on 5 August 2012. ${ }^{4}$ The second set of

1 The governments of the People's Republic of China (PRC) and the Republic of China (Rоc) adhere to the principle of "One China" under the "92 Consensus," "One China Structure," or "One China Framework." The current Tsai Ing-wen administration refuses to accept the principle and the consensus. Throughout this paper, China is referred to as the PRC and Taiwan is referred to as the ROC. China, Taiwan, the PRC, and the ROC will be used interchangeably.

2 Ibid.

3 Chinese, Japanese Leaders Call for Maintaining Good Momentum of Bilateral Ties, People's DAILY ONLINE (19 November 2006), available at http://english.peopledaily.com.cn/ 200611/19/eng20061119_323010.html; Chinese Premier Advocates Five Principles for Promoting Sino-Japanese Ties, People's Daily Online (12 April 2007), available at http://english. peopledaily.com.cn/200704/12/eng20070412_36 5829.html; Chinese, Japanese Leaders Reach Consensus on East China Sea Issue, Gov.cN (28 December 2007), available at http://www.gov .cn/misc/2007-12/28/content_846359.htm; Ministry OF Foreign AfFairs of JaPAN, Joint Statement Between the Government of Japan and the Government of the People's Republic of China on Comprehensive Promotion of a "Mutually Beneficial Relationship Based on Common Strategic Interests" (7 May 2008), available at http://www.mofa.go.jp/region/asia-paci/china/ jointo805.html; Ministry of Foreign Affairs of the People's Republic of China, China and Japan Reach Principled Consensus on the East China Sea Issue (18 June 2008), available at http://www.fmprc.gov.cn/eng/xwfw/s2510/t466632.htm.

4 For the initiative, visit the website of the Republic of China, available at http://www.mofa .gov.tw/EnOfficial/Topics/TopicsIndex/?opno=cc7f748f-f55f-4eeb-91b4-cf4a28bbb86f.

(C) YANN-HUEI SONG, 2019 | DOI:10.1163/9789004379633_003

This is an open access article distributed under the terms of the prevailing CC-BY-NC License at the time of publication. 
agreements on maritime cooperation refer to the fisheries agreement signed between China and Japan in November 1997, entered into force in June 2000, ${ }^{5}$ and the Principled Common Understanding on the East China Sea Issues (hereafter referred to as "the 2008 Understanding") between the two countries in June $2008,{ }^{6}$ and the fisheries agreement signed by Chairman Liao Liou-yi of Taiwan's Association for East Asian Relations and Chairman Mitsuo Ohashi of Japan's Interchange Association on 10 April 2013. ${ }^{7}$ These proposals and agreements have the potential not only to help govern the activities that are related to exploration, exploitation, preservation, or protection of the living and nonliving resources of the East China Sea, but also to manage the conflicts that arise from the sovereignty and maritime disputes over the Diaoyutai/Diaoyu/ Senkaku island group (hereafter referred to as "the DIG") among the three parties in this important East Asian semi-enclosed sea. In the long run, it is hoped that these peaceful proposals and agreements on maritime cooperation, if carried out faithfully and successfully, can help transform the East China Sea from a sea of confrontation into a sea of peace, friendship and cooperation. Before reaching that goal, however, there exist a number of challenges that face China, Japan, and Taiwan. One of the biggest challenges concerns the possibility of combining these bilateral or unilateral peaceful proposals and bilateral agreements on maritime cooperation into a multilateral peaceful proposal and agreement that are acceptable to all of the three parties.

The purpose of this article is to discuss the progress that has been made so far and the challenges that lie ahead with regard to the future development and implementation of the peaceful proposals and agreements on maritime cooperation made or agreed to between China, Japan, and Taiwan in the East

5 For the English text of the Agreement on Fisheries Between the Government of the People's Republic of China and the Government of Japan, see Guifang Xue, China And International Fisheries LaW AND Policy 295-299 (2005), Appendix 6.

6 For the text of the Understanding, visit the website of the Center for International Law, National University of Singapore, available at http://cil.nus.edu.sg/rp/il/pdf/2008\%20China -Japan\%2oPrincipled\%2oConsensus\%20on\%2othe\%2oEast\%2oChina\%2oSea\%2oIssue -pdf.pdf. See also, Gao Jianjun, A Note on the 2008 Cooperation Consensus Between China and Japan in the East China Sea, 40 OCean Development ANd International LaW 302-303 (2009).

7 For more information about the signing of the agreement, visit the website of the Republic of China, available at http://www.mofa.gov.tw/EnOfficial/ArticleDetail/DetailDefault/fo

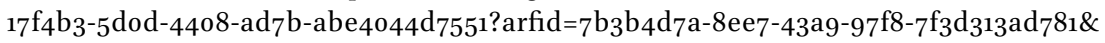
opno $=84$ ba3639-be $42-4966-\mathrm{b} 873-78 \mathrm{a} 267 \mathrm{de} 8 \mathrm{cfi}$. For the text of the agreement (in Chinese), available at http://news.stnn.cc/hk_taiwan/201304/ t20130411_1879091.html. For the text of the agreement in Japanese, available at http://www.koryu.or.jp/taipei/ez3_contents.nsf/o4/ ${ }_{9} \mathrm{~B} 1 \mathrm{FF} 4136002 \mathrm{E} 58149257 \mathrm{~B} 4 \mathrm{Aoo2} 6702 \mathrm{D} /$ file/20130410torikime.pdf. 
China Sea between 1997 and 2013. The paper is organized into six parts. Following this introductory part, Part two provides a background explanation on the development of these peaceful proposals and maritime cooperation-related agreements. Part three examines the content of these proposals and agreements. Part four discusses the current status of the proposals and agreements and their implementation. Part five examines the challenges China, Japan, and Taiwan are facing individually, bilaterally, or collectively. Concluding remarks are made in Part six that ends the article.

\section{Background Explanation on Peace and Maritime Cooperation-} related Developments in the ECS

\section{$1 \quad$ Agreement on Fisheries between China and Japan}

On 16 November 1994, the United Nations Convention on the Law of the Sea (hereafter referred to as "the Los Convention") entered into force. ${ }^{8}$ Japan signed the Convention on 7 February 1983 and ratified it on 20 June 1996, which entered into force for Japan on 20 July, 1996. China signed the Convention on 10 December 1982 and ratified it on 15 May 1996. The Los Convention entered into force for China on 7 July 1996.

Immediately after becoming a party to the Los Convention, Japan amended its Law on the Territorial Sea and the Contiguous Zone ${ }^{9}$ and enacted the Law on the EEZ and the Continental Shelf. ${ }^{10}$ Japan claims that its EEZ comprises the areas of the sea extending from the baseline of Japan, which are measured 200 nautical miles $(\mathrm{nm})$ from the nearest point on the Japanese baseline and its subjacent seabed and its subsoil. The continental shelf claimed by Japan comprises the seabed and its subsoil to the following areas: (1) the areas of the sea extending from the baseline of Japan "to the line in which every point is 200 nautical miles from the nearest point on the baseline of Japan (excluding from its territorial sea)"; (2) "the areas of the sea adjacent seaward to the areas

8 United Nations Convention on the Law of the Sea, opened for signature 1o December 1982, 1833 UNTs 397, available at http://www.un.org/Depts/los/convention_agreements/ texts/unclos/unclos_e.pdf. As of 30 January 2013, 164 countries and the European Union were parties to the LOS Convention. For status of the Convention, visit the UN website, available at http://www.un.org/Depts/los/reference_files/status2010.pdf.

9 See Bureau of Oceans and Int'L Environmental and Scientific Affairs, U.S. Dep't of State, Pub. no. 120, Limits in the Seas: Straight Baseline and TerRitorial SEA Claims: JaPAN (1998), available at http://www.state.gov/documents/organization/57684.pdf.

10 See Law on the Exclusive Economic Zone and Continental Shelf (Law No. 74 of 1996), http://www.un.org/Depts/los/legislationandtreaties/pdffiles/jpn_1996_Law74.pdf. 
of the sea referred to" above as prescribed by the Japanese Cabinet Order in accordance with Article 76 of the UNCLOS. ${ }^{11}$ In cases of overlapping with the EEZ and the continental shelf claimed by the states with opposite coasts, the problem of maritime boundary delimitation should be resolved by drawing a median line, or the line which "may be agreed upon between Japan and a foreign country as a substitute for the median line."12

On 26 June 1998, China enacted its Law on the Exclusive Economic Zone and the Continental Shelf. ${ }^{13}$ Article 2 of the law provides that the E Ez of China is an area beyond and adjacent to its territorial sea extending to a distance of $200 \mathrm{~nm}$ from the baselines from which the breadth of Chinese territorial sea is measured. Under the same article, the Chinese continental shelf "comprises the seabed and subsoil of the submarine areas that extend beyond its territorial sea throughout the natural prolongation of its land territory to the outer edge of the continental margin, or to a distance of $200 \mathrm{~nm}$ from the baselines from which the breadth of the territorial sea is measured where the outer edge of the continental margin does not extend up to that distance." China exercises sovereign rights and jurisdiction in its EEZ and continental shelf. ${ }^{14}$ In addition, Article 14 of the law provides that "The provisions of this Act shall not affect the historical rights of the People's Republic of China."

Under Article 61 of the Los Convention, both Japan and China should ensure through proper conservation and management measures that the maintenance of the living resources in the EEZ is not endangered by overexploitation. Under Article 74, Japan and China should enter into negotiation to delimit their EEzs. However, if no agreement can be reached, Japan and China should "make every effort to enter into provisional arrangements of a practical nature and, during this transitional period, not to jeopardize or hamper the reaching of the final agreement. Such arrangements shall be without prejudice to the final delimitation."15

In the face of aggressive fishing activities by an increasing number of Chinese fishing vessels in the East China Sea,Japan asked China to enter into negotiation

\footnotetext{
$11 \quad$ Ibid. art. $1, \S 2$.

12 Ibid. art. 1, § 2, art. 2.

13 Law on the Exclusive Economic Zone and the Continental Shelf of the People's Republic of China, adopted at the 3 rd Meeting of the Standing Committee of the Ninth National People's Congress on 26 June 1998 and promulgated by Order No. 6 of the President of the People's Republic of China on 26 June 1998, available at http://www.asianlii.org/cn/legis/ cen/laws/loteezatcsotproc79o/.

14 Arts. 3 and 4, ibid.

15 Art. 74(3), LOS Convention.
} 
for a new fisheries arrangement in the overlapping EEZ area. ${ }^{16}$ After intense and difficult negotiations, China and Japan signed the Agreement on Fisheries on 11 November $1997 \cdot{ }^{17}$ The new fisheries agreement shelved a territorial dispute over the DIG in the East China Sea. On 1 June 2000, the Agreement on Fisheries between the Government of People's Republic of China and the Government of Japan entered into force.

\section{$2 \quad$ The 2008 Understanding}

Between 2003 and 2008, China and Japan were at odds over the right to explore and exploit oil and gas resources in the East China Sea. In August 2003, China set up a production platform at the Chunxiao oilfield, which prompted Japan to lodge a strong protest, asserting that the Chinese drilling in the area about 5 kilometers west of the Japanese claimed median line in the East China Sea would siphon off oil and gas reserves from Japan's side. Japan called on China to suspend production close to the median line pending a diplomatic resolution of the dispute and to share geological data on the Chinese gas fields in the area. In July 2004, Japan conducted its own survey in the area near the disputed median line in the East China Sea by chartering a Norwegian seismic survey ship. For the purpose of managing the conflict arising from China's oil and gas exploration activities in the East China Sea, Tokyo and Beijing agreed to send governmental officials to talk about the issue. The first round of the Sino-Japanese talks took place in October 2004.

In September 2005, in response to an experimental drilling conducted by the Japanese Teikoku Oil Company in the areas near the Chinese natural gas fields in the East China Sea in July 2005, China deployed a fleet of five warships near the Chunxiao gas field. In March 2006, China National Offshore Oil Corporation said that it was proceeding with work to develop natural gas reserves in the disputed areas of the East China Sea where Japan rejected a proposal to jointly explore for natural gas with China. In April 2006, China lodged an official protest when Japan's Education Ministry approved the textbooks in which it is stated that the Diaoyutai Islands are part of the Japanese territory. In the same month, Japan lodged complaints with Beijing, saying that China had conducted aerial surveys several times beyond the Japanese claimed median line in the East China Sea.

16 Park Hee Kwon, The law of the Sea and northeast Asia: A Challenge for Cooperation 52 (2000); Guifang Xue, China And International Fisheries LaW and Policy 182 (2005); Zou Keyuan, LaW of the Sea in East Asia: Issues and Prospects 99-100 (2005).

17 Japan, China Sign New Bilateral Fisheries Pact, Japan Economic Newswire, 11 November 1997 . 
In June 2008, after 11 rounds of serious consultations, China and Japan reached the Principled Common Understanding on the East China Sea Issues. Paragraph 1 of the Understanding provides that

In order to make the East China Sea, of which the delimitation between China and Japan is yet to be made, a "sea of peace, cooperation and friendship," China and Japan have, in keeping with the common understanding reached by leaders of the two countries in April 2007 and their new common understanding reached in December 2007, agreed through serious consultations that the two sides will conduct cooperation in the transitional period prior to delimitation without prejudicing their respective legal positions. The two sides have taken the first step to this end and will continue to conduct consultations in the future.

In addition, Japanese companies are allowed to participate in the development of Chunxiao oil and gas field in accordance with the relevant Chinese laws that govern cooperation with foreign enterprises in the exploration and exploitation of offshore petroleum resources. In addition, the two sides agreed to establish a block for joint development in the East China Sea. ${ }^{18}$ To carry out this joint development proposal, China and Japan will work to fulfill their respective domestic procedures and arrive at the necessary bilateral agreement at an early date. The two sides also agreed to continue consultations for the early realization of joint development in other parts of the East China Sea. ${ }^{19}$

\section{$3 \quad$ The East China Sea Peace Initiative}

In the same month that the 2008 Understanding was released, a Taiwanese vessel Lienhe collided with a Japanese Coast Guard patrol boat in the waters near the disputed DIG in the southern part of the East China Sea. The vessel sank following the collision, but all three of its crew members and 13 passengers were rescued by the Japanese patrol boat. Japanese authorities detained the captain of

18 The block for joint development is the area that is bounded by straight lines joining the following points in the order listed:

1. Latitude $29^{\circ} 31^{\prime}$ North, longitude $125^{\circ} 53^{\prime} 30^{\prime \prime}$ East

2. Latitude $29^{\circ} 49^{\prime}$ North, longitude $125^{\circ} 53^{\prime} 30^{\prime \prime}$ East

3. Latitude $30^{\circ} 04^{\prime}$ North, longitude $126^{\circ} 03^{\prime} 45^{\prime \prime}$ East

4. Latitude $30^{\circ} 00^{\prime}$ North, longitude $126^{\circ} 10^{\prime} 23^{\prime \prime}$ East

5. Latitude $30^{\circ} 00^{\prime}$ North, longitude $126^{\circ} 20^{\prime}$ oo" East

6. Latitude $29^{\circ} 55^{\prime}$ North, longitude $126^{\circ} 26^{\prime}$ oo" East

7. Latitude $29^{\circ} 31^{\prime}$ North, longitude $126^{\circ} 26^{\prime}$ oo" East

19 For the text of the common understanding reached between Japan and China on 18 June 2008, available at http://news.xinhuanet.com/english/2008-o6/18/content_8394206.htm. 
the vessel for three days for questioning, prompting Taipei to file a formal protest with Tokyo to complain about the act. ${ }^{20}$ The incident ended with apologies and compensation from the Japanese government to the Taiwanese boat captain. ${ }^{21}$

On 30 June 2008, a group of Japanese lawmakers viewed the areas around the DIG by airplane, which immediately drew strong protests from China and Taiwan. ${ }^{22}$ In December 2008, two Chinese marine surveillance vessels, the 1,100-tonne Haijian 46 and 1,700-tonne Haijian 51, entered the Japanese claimed territorial waters around the Diaoyutai Islands. Japan immediately lodged a diplomatic protest against the act. ${ }^{23}$ In response, the Chinese Foreign Ministry spokesman stated that "[t]he Diaoyu Islands and its adjacent islets are parts of Chinese territories since ancient times. The Chinese ships are justified in conducting usual patrol in waters within China's jurisdiction."24

In April 2010, 10 Chinese People's Liberation Army-Navy (PLAN) vessels, including two submarines and eight warships, sailed through international waters between the islands of Okinawa and Miyako in the East China Sea, heading southeast into the Pacific Ocean. Japanese Maritime Self-Defense Force (MSDF) sent destroyers to follow the Chinese warships and monitor the passing activities. In response, China sent a navy helicopter to fly close to the Japanese MSDF destroyer, which drew protest from the government of Japan. While Japan argued that it was a dangerous act for the navigation of the Japanese vessel, China considered it a "necessary defense measure" in response to the Japanese surveillance activities. ${ }^{25}$ In July 2010, Chinese navy conducted live-firing exercises in the East China Sea. ${ }^{26}$

20 Tensions rise in Taiwan over boat sinking in disputed waters with Japan, В ВС MONITORING Asia Pacific - Political, 12 June 2008.

21 Japan apologies, offers compensation to Taiwan over boat sinking, JAPANTODAY: Japan News and Discussion, 25 June 2008, available at http://www.japantoday.com/category/ national/view/japan-apologizes-offers-compensation-to-taiwan-over-boat-sinking.

22 Japanese MPs view disputed islets from air amidst China, Taiwan protests, B BC MONITORing Asia Pacific - Political, 1 July 2008.

23 For the protest dated 19 December 2008, see website of the Japanese House of Representatives (in Japanese) available at http://www.shugiin.go.jp/itdb_shitsumon.nsf/html/ shitsumon/ b170326.htm.

24 Foreign Ministry Spokesman Liu Jianchao's Remarks on Chinese Marine Surveillance Ships Entering the Waters near the Diaoyu Islands, 8 December 2008, see website of the Chinese Foreign Ministry, available at http://www.fmprc.gov.cn/eng/xwfw/s2510/2535/t525428. htm.

25 Japan lodges protest with China over navy helicopter approach, ввС MONITORING AsIA PACIFIC - PoliticAL, 21 April 2010; China says navy chopper approach to Japanese ship necessary measures, ввC Monitoring Asia PaCific - Political, 23 April 2010.

26 Goh Sui Noi, China needs to show its rise is benign, The Straits Times (Singapore), 16 August 2010; Chinese navy organizes military drill in E Sea, CHINA DAILY, 7 July 2010, available at http://www.chinadaily.com.cn/photo/2010-07/07/content_10074475.htm. 
On 7 September 2010, "the most serious China-Japan conflict in decades"27 erupted in the East China Sea, in which a Chinese fishing boat collided with two Japanese patrol vessels in the waters near the DIG. Japan detained the boat's captain together with 14 crew members on the ground of obstructing the public duties of Japanese law enforcement personnel. On 13 September 2010, nearly a week after the incident occurred, Japan released the Chinese crew members, but kept the captain in custody before deciding whether to press charges against him. China lodged a protest and demanded Japan to release the detained boat captain immediately. ${ }^{28}$ Beijing signaled its anger by taking a number of actions, which included postponing the scheduled talks with Japan about the follow-up matters relating to the Principled Common Understanding, canceling a scheduled cultural exchange visit of 1,00o Japanese youth to the Shanghai World Expo, blocking crucial exports to Japan of rare earth, and detaining four Japanese construction company employees in the Chinese province of Hebei for videotaping military installation. ${ }^{29}$ The fishing boat incident ended on 25 September 2010 when Japan released the Chinese captain. ${ }^{30}$

Tensions in the East China Sea have risen since April 2012 when the former Japanese Tokyo governor Shintaro Ishihara announced his plan to purchase the disputed islands in Washington at the Heritage Foundation. ${ }^{31}$ On 7 July 2012, the Japanese Noda administration announced its plan to purchase Diaoyu Dao, the largest of the DIG, and Bei Xiaodao and Nan Xiaodao nearby. ${ }^{32}$

27 See Tanaka Sakai, Rethinking China-Japan Conflict:The Senkaku/Diaoyutai Islands Clash, a translation of an article 日中対立の再燃 that appeared in TANAKA NEWs, 1 September 2010 with a follow-up story on 21 September 2010, available at http://www.japanfocus.org/ articles/print_article/3418.

28 China ProtestsJapan's Seizure of Chinese Fishing Boat near Diaoyu Island, CAIJING MAGAZINE, 9 September 2010, available at http://english.caijing.com.cn/templates/inc/webcontentens.jsp?id=110516865\&time=2010-09-09\&cl=104\&page $=$ all.

29 China postpones E China Sea negotiation with Japan, ChINA DaILY, 11 September 2010, available at http://www.chinadaily.com.cn/china/2010-09/11/content_11288437.htm; Jacob M. Schlesinger and Yuka Hayashi, Japanese Youth Scrap Shanghai Expo Visit, THE Wall Street Journal, 20 September 2010, available at http://blogs.wsj.com/japanrealtime/2010/og/20/japanese-youth-scrap-shanghai-expo-visit/; Keith Bradsher, Amid Tension, China Blocks Crucial Exports to Japan, The New York Times, 23 September 2010, available at http://www.nytimes.com/2010/og/24/business/global/24rare.html; and Minoru Matsutani and Kanako Takahara, Four Fujita employees held in Hebei Province, The Japan Times, 25 September, 2010, available at http://search.japantimes.co.jp/cgi -bin/nn20100925a3.html.

30 Martin Fackler and Ian Johnson, Japan Retreats with Release of Chinese Boat Captain, THE New York Times, 24 September 2010.

31 Yuka Hayashi, Tokyo Chief Plots to Buy Disputed Islands, The Wall Stre et Journal, 17 April 2012.

32 Navy to launch live-fire drill in disputed waters; Exercise to be staged as tensions rise between Beijing and Tokyo over the Diaoyu Islands, South China Morning Post, 10 July 2012. 
In August 2012, mainly in response to the rising tension in the East China Sea, and under increasing domestic political pressures that asked the government to take stronger actions to safeguard Taiwan's sovereignty over the DIG and protect the right of fishermen to fish in the waters off the disputed islands, Taiwan's President Ma Ying-jeou proposed the five points East China Sea Peace Initiative. This was followed by the guidelines to implement the ECSPI that were announced on 7 September 2012 at one of Taiwan's offshore islands located in the East China Sea. ${ }^{33}$

\section{$4 \quad$ Agreement on Fisheries between Japan and Taiwan}

In January 1998, Taiwan enacted the Law on the Territorial Sea and the Contiguous Zone ${ }^{34}$ and the Law on the Exclusive Economic Zone and the Continental Shelf. ${ }^{35}$ In February 1999, the base points and baselines were announced by Taiwan in the first part of the baselines of the territorial sea of the Rос. ${ }^{36}$ Taiwan's EEZ and continental shelf claim is identical with that of China's. ${ }^{37}$ Article 4 of Taiwan's EEz law also provides that before reaching agreements with adjacent or opposite countries, Taiwan, in a spirit of understanding and co-operation, may reach a modus vivendi with the countries concerned, which however should be without prejudice to the final delimitation. ${ }^{38}$

Between 1996 and 2012, sixteen rounds of fisheries talks between Taiwan and Japan were held. ${ }^{39}$ Taiwan proposed to Japan that a jointly management zone be established in waters off the disputed DIG so both sides can fish in each country's overlapping EEZ, but Japan rejected the proposal.

33 East China Sea Peace Institute Implementation Guidelines, Ministry of Foreign AfFAIRs RePUblic of CHINA (TAIWAN) (7 September 2012), available at http://www.mofa. gov.tw/EnOfficial/Topics/TopicsArticleDetail/9d66bed6-16fa-4585-bc7c-c0845f2dfc39 [hereinafter Initiative].

34 Law on the Territorial Sea and the Contiguous Zone of 25 February 1992, available at http://www.library.uoregon.edu/ec/e-asia/read/sealaw.pdf.

35 See Bureau of Oceans and Int'L Environmental and Scientific Affairs, U.S. Dep't of State, Pub. No. 127, Limits in the Seas: Taiwan's Maritime Claims (2005), available at http://www.state.gov/documents/organization/57674.pdf [hereinafter Taiwan's Maritime Claims].

36 Decree No. Tai 88 Nei Tze \#o6161, Executive Yuan Gazette (Taiwan), 10 February 1999, at 36 .

37 Taiwan's Maritime Claims, supra note 35, at 26-33.

38 Law on the Exclusive Economic Zone and the Continental Shelf of the Republic of China (26 June 1998), available at http://www.un.org/Depts/los/legislationandtreaties/pdffiles/ chn_1998_eez_act.pdf.

39 Japan, Taiwan to Hold Second Preparatory Fish Talks, The Japan Times, 26 December 2012), available at http://www.japantimes.co.jp/news/2012/12/26/national/japan-taiwanto-hold-second-preparatory-fishery-talks/\#.usiq;FfshBk [hereinafter Japan-Taiwan Fish Talks]. 
In November 2012, the first preparatory meeting for the 17 th round of JapanTaiwan Fishery Talk was held in Tokyo ${ }^{40}$ and the second preparatory meeting was to be held in January or February $2013 .{ }^{41}$ The meeting was further postponed because a boat with Taiwanese activists that headed for the disputed waters near Dioayutai/Senkaku Islands but was turned back on 24January 2013 after coastguard vessels from Japan and Taiwan converged and dueled with water cannon. ${ }^{42}$ On 10 April 2013, at the 17 th round of Taiwan-Japan Fishery Talk, a fisheries agreement was signed by Taiwan's Association for East Asian Relations and Japan's Interchange Association. The agreement includes an escape clause which Taipei said allows both sides to set aside disputes over their competing sovereignty claims. ${ }^{43}$

\section{The Content of the Peaceful Proposals and the Agreements}

The Chinese-Japanese Peaceful Proposals

In November 2006, Chinese President Hu Jintao and Japanese Prime Minister Shinzo Abe met in Hanoi, Vietnam when attending the APEC meeting. The two leaders agreed: (1) to speed up consultation on the East China Sea issue in line with the principle of mutual benefit and reciprocity; (2) to adhere to negotiation and dialogue; (3) to put aside disputes and pursue joint development; and (4) to make East China Sea the "sea of peace, cooperation and friendship."

In April 2007, the Chinese Premier Wen Jiabao paid an official visit to Japan. During the visit, Japan and China reached the following five common understandings on properly addressing the East China Sea issue: (1) both sides are committed to making the East China Sea a sea of peace, cooperation and friendship; (2) they agreed to carry out joint development based on the principle of mutual benefit as a temporary arrangement pending the final demarcation and without prejudice to the positions of either side on matters concerning the law of the sea; (3) they will conduct consultation at higher level when necessary;

40 Taiwan, Japan Make Little Progress at Fishery Talks, Want China Times, 1 December 2012, available at http://www.wantchinatimes.com/news-subclass-cnt.aspx?id=201212010 00074\&cid=1101.

41 Japan-Taiwan Fish Talks, supra note 39.

42 Amber Wang, Taiwanese Activists And Japanese Coast Guard Have Water Cannon Duel Near Disputed Islands, Business Insider, 24 January 2013, available at http://www. businessinsider.com/taiwanese-activists-and-japanese-coast-guard-have-water-cannonduel-near-disputed-islands-2013-1.

Taiwan, Japan ink fisheries agreement, TAIPEI TIMEs, 11 April 2013, available at http://www .taipeitimes.com/News/front/archives/2013/04/11/2003559323. 
(4) they will carry out joint development in larger waters acceptable to them; and (5) they will speed up consultations and hope to submit a detailed plan on joint development to the leaders of the two countries in autumn of 2007.

In December 2007, the Chinese and Japanese leaders reached a 4-point new consensus on the East China Sea issue: (1) to continue to adhere to the fivepoint consensus achieved by leaders of the two countries in April 2007 in a bid to turn the East China Sea into a sea of peace, cooperation and friendship; (2) the two sides have elevated the level of consultation, conducted earnest and substantive consultation on the concrete solution to the issue and made positive progress; (3) to conduct vice ministerial-level consultation, if necessary, while maintaining the current consultation framework; (4) the solution to the East China Sea issue conformed with the interests of both China and Japan. The two sides agreed to strive for an early solution in the process of developing bilateral ties. In May 2008, China and Japan issued a joint statement on promoting strategic, mutually beneficial ties. The two sides pledged again to work together and make the East China Sea a sea of peace, cooperation and friendship. The proposal to make the East China Sea a "sea of peace, cooperation and friendship" is reiterated in the 2008 Understanding.

\section{$2 \quad$ The East China Sea Peace Initiative}

The five points East China Sea Peace Initiative calls all parties concerned to: (1) Refrain from taking any antagonistic actions; (2) Shelve controversies and not abandon dialogue; (3) Observe international law and resolve disputes through peaceful means; (4) Seek consensus on a code of conduct in the East China Sea; and (5) Establish a mechanism for cooperation on exploring and developing resources in the East China Sea. ${ }^{44}$

This peace proposal, based on the principle of "safeguarding sovereignty, shelving disputes, pursuing peace and reciprocity, and promoting joint exploration and development," 45 was followed by the implementation guidelines that were announced on 7 September 2012 at one of Taiwan's offshore islands located in the East China Sea. ${ }^{46}$

Taiwan's East China Sea Peace Initiative will be implemented in two stages: (1) peaceful dialogue and mutually reciprocal negotiation; and (2) sharing resources and cooperative development. The first stage involves (1) promoting

44 For the proposal, visit the website of Ministry of Foreign Affairs Republic of China (TAIwAN), available at http://www.mofa.gov.tw/EnOfficial/Topics/Topics Index/?opno=cc7f f48f-f55f-4eeb-91b4-cf $4 a 28$ bbb86f.

$46 \quad$ Initiative, supra note 33 . 
the idea of resolving the East China Sea dispute through peaceful means; (2) establishing channels for Track I and Track II dialogue; and (3) encouraging all parties concerned to address key East China Sea issues via bilateral or multilateral negotiation mechanisms to bolster mutual trust and collective benefit. ${ }^{47}$ During the second stage, the main task is to institutionalize all forms of dialogue and negotiation, to encourage all parties concerned to implement substantive cooperative projects, and to establish mechanisms for joint exploration and development of resources that form a network of peace and cooperation in the East China Sea area. ${ }^{48}$

Key issues for the implementation of the peace initiative include fishing industry, mining industry, marine science research and maritime environmental protection, maritime security and unconventional security, and East China Sea Code of Conduct. ${ }^{49}$ This is to be done by moving from three parallel tracks of bilateral dialogue (between Taiwan and Japan, Taiwan and China, and Japan and China) to one track of trilateral negotiations (among China, Japan and Taiwan) to realize peace and cooperation in the East China Sea. ${ }^{50}$

\section{$3 \quad$ The 2008 Understanding}

In June 2008, after 11 rounds of serious consultation, China and Japan reached the Principled Common Understanding on the East China Sea Issues. It is stated clearly in the Understanding that in order to make the East China Sea a "sea of peace, cooperation and friendship," China and Japan agreed to conduct cooperation in the transitional period prior to maritime boundary delimitation without prejudicing their respective legal positions.

As the first step in the joint development of the East China Sea between China and Japan, the two sides agreed to establish a block for joint development in the East China Sea, which shall be the area bounded by straight lines joining the following points in the order listed:

1. Latitude $29^{\circ} 31^{\prime}$ North, longitude $125^{\circ} 53^{\prime} 30^{\prime \prime}$ East

2. Latitude $29^{\circ} 49^{\prime}$ North, longitude $125^{\circ} 53^{\prime} 30^{\prime \prime}$ East

3. Latitude $30^{\circ} 04^{\prime}$ North, longitude $126^{\circ} 03^{\prime} 45^{\prime \prime}$ East

4. Latitude $30^{\circ}$ oo' North, longitude $126^{\circ} 10^{\prime} 23^{\prime \prime}$ East

5. Latitude $30^{\circ} 00^{\prime}$ North, longitude $126^{\circ} 20^{\prime} 00^{\prime \prime}$ East

6. Latitude $29^{\circ} 55^{\prime}$ North, longitude $126^{\circ} 26^{\prime}$ oo" East

7. Latitude $29^{\circ} 31^{\prime}$ North, longitude $126^{\circ} 26^{\prime}$ oo" East 
To carry out the above-mentioned joint development, the two sides will work to fulfill their respective domestic procedures and arrive at the necessary bilateral agreement at an early date. In addition, China and Japan agreed to continue consultations for the early realization of joint development in other parts of the East China Sea.

In addition, the Japanese companies are allowed to participate in the development of Chunxiao oil and gas field in accordance with the relevant Chinese laws that govern cooperation with foreign enterprises in the exploration and exploitation of offshore petroleum resources. The governments of China and Japan will work to reach agreement on the exchange of notes as necessary and exchange them at an early date. The two sides will fulfill their respective domestic procedures as required. ${ }^{51}$

4

The 1997 China-Japan Fisheries Agreement

Before signing the Fisheries Agreement in November 1997, fisheries relations between China and Japan were governed by the Fisheries Agreement which was signed by the two countries on 15 August 1975 and brought into force on 22 December 1975. The 1975 Fisheries Agreement formalized the three previous ones concluded in 1955, 1963 and 1965 respectively between the Japan-China Fisheries Council of Japan and the China Fisheries Council. The Fisheries Agreement, signed in November 1997 and entered into force on 1 June 2000, establishes a new fishery order in the East China Sea for the two countries in accordance with the Los Convention. It aims to conserve and utilize rationally marine living resource of common concern, and maintain the orderly conduct of maritime fishing operations in the East China Sea. This agreement has 14 articles and 2 annexes.

The 1997 Fisheries Agreement applies to the EEzs of China and Japan in the East China Sea. ${ }^{52}$ Nationals and fishing boats of each party engaged in fishery activities in the other's EEz should comply with this Agreement and the other's relevant laws and regulations. ${ }^{53}$ Both China and Japan are required to adopt necessary measures to ensure compliance by their nationals and fishing boats with the provisions of the Agreement and the conservation measures and other conditions provided for in the relevant laws and regulations of the other Party when they are engaged in fishery activities in the other's EEZ, and should inform each other of such conservation measures and other conditions provided for in its relevant laws and regulations. ${ }^{54}$ The two countries also agree

$5^{1} \quad$ For the text of the common understanding reached between Japan and China on 18 June 2008, available at http://news.xinhuanet.com/english/2008-06/18/content_8394206.htm.

52 Article 1.

53 Article 2.

54 Article 4. 
to cooperate to conduct scientific research in fishery and to conserve marine living resources. ${ }^{55}$

Under the Fisheries Agreement, there are three types of waters: EEzs, Provisional Waters, and waters for maintaining current fishing activity. First, the EEZ waters extend to $5^{2}$ miles from the baselines that measure the Chinese and Japanese territorial waters respectively. In these waters, both China and Japan have exclusive rights over the exploitation, conservation and utilization of marine living resources. Considering the status of fishery resources, its fishing capacity, traditional fishing activities and the reciprocal fishing situation, and other relevant matters in the EEZ, each party to the agreement decides annually on the fish species, amount of catch allocation, fishing area, and other fishing conditions under which it will allow the other party's fishermen and fishing vessels to operate. In deciding these fishing conditions, each contracting party respects the result of consultations with the Sino-Japanese Fishery Joint Committee. ${ }^{56}$ Each contracting party can take necessary measures in accordance with international law to ensure that the other party's fishermen and fishing vessels obey conservation measures for marine living resources and other conditions provided in its relevant laws and ordinances. ${ }^{57}$ Each contracting party's fishing vessels need a fishing licence issued by the other coastal country to fish in its EEz. In the case of seizure or detention, the fishing vessel and crew must be released rapidly after paying a security or submitting a guarantee. ${ }^{58}$

Second, in the waters where it is difficult to distinguish each party's EEZ boundary, a Provisional Measures Zone is established (See Figure 1). The zone is enclosed by straight lines connecting in order the following coordinates:

1. Latitude $30^{\circ} 40^{\prime}$ North, longitude $124^{\circ} 10^{\prime} 1$ " East

2. Latitude $30^{\circ} 00^{\prime}$ North, longitude $123^{\circ} 56^{\prime} 4^{\prime \prime}$ East

3. Latitude $29^{\circ} 00^{\prime}$ North, longitude $123^{\circ} 25^{\prime} 5^{\prime \prime}$ East

4. Latitude $28^{\circ} 00^{\prime}$ North, longitude $122^{\circ} 47^{\prime} 9^{\prime \prime}$ East

5. Latitude $27^{\circ} 00^{\prime}$ North, longitude $121^{\circ} 57^{\prime} 4^{\prime \prime}$ East

6. Latitude $27^{\circ} 00^{\prime}$ North, longitude $125^{\circ} 5^{\circ} 3^{\prime \prime}$ East

7. Latitude $28^{\circ} 00^{\prime}$ North, longitude $127^{\circ} 15^{\prime} 1^{\prime \prime}$ East

8. Latitude $29^{\circ} 00^{\prime}$ North, longitude $128^{\circ} 0^{\prime} 9^{\prime \prime}$ East

9. Latitude $30^{\circ} 00^{\prime}$ North, longitude $128^{\circ} 32^{\prime} 2$ " East

10. Latitude $30^{\circ} 40^{\prime}$ North, longitude $128^{\circ} 26^{\prime} 1$ " East

11. Latitude $30^{\circ} 40^{\prime}$ North, longitude $124^{\circ} 10^{\prime} 11^{\prime \prime}$ East ${ }^{59}$

59 Article 7 (1). 
Each contracting party has to take appropriate conservation measures and quantitative management measures to ensure that the maintenance of marine living resources is not threatened by over-exploitation, in accordance with the decision of the China-Japan Fishery Joint Committee and taking into consideration the effect on traditional fishing activities conducted by each contracting party in the Provisional Measures Zone. ${ }^{60}$ In this area of waters, neither country can apply its laws or regulations to the other country's fishing vessels and fishermen. When one contracting party detects a violation by the other party's fishing vessels or fishermen, it can notify the other party of the violation and related details. The other party investigates the fact, takes any necessary measures and informs the other party of the results of these measures. ${ }^{61}$

Third, the waters south of latitude $27^{\circ}$ North and west of latitude $125^{\circ} 30^{\prime}$ East in the East China Sea, are not included in the Provisional Measures Zone. However, the relevant laws and regulations of one country are not applied to the other country's fishermen and fishing vessels. ${ }^{62}$

To achieve the objectives of the agreement, the China-Japan Fishery Joint Committee is established. It consists of two representatives appointed by each contracting party. The Committee recommends the following: fish species, amount of catch allocation, fishing area, and other conditions to allow the other party's fishermen and fishing vessels to fish under Article 3; the maintenance of fishing order; the status and conservation of marine living resources; and fishery co-operation. The Committee discusses and determines the conservation and management of marine living resources in the Provisional Waters based on Article 7.63

\section{$5 \quad$ The 2013 Taiwan-Japan Fisheries Agreement}

After 17 years of effort, Taiwan and Japan finally concluded a major fisheries agreement. The purposes for signing the agreement include: (1) maintaining peace and stability in the East China Sea; (2) promoting friendly relations and reciprocity and cooperation between Taiwan and Japan; (3) ensuring conservation and rational utilization of marine living resources of the EEzs and (4) maintaining fishery operation order. ${ }^{64}$ The agreement establishes a maritime zone, which is enclosed by connecting the following points (See Figure 2):

\begin{tabular}{ll}
\hline 60 & Article $7(2)$. \\
61 & Article 7(3). \\
62 & Article 6. \\
63 & Article 11. \\
64 & Article 1.
\end{tabular}




\section{Joint Management Zone}

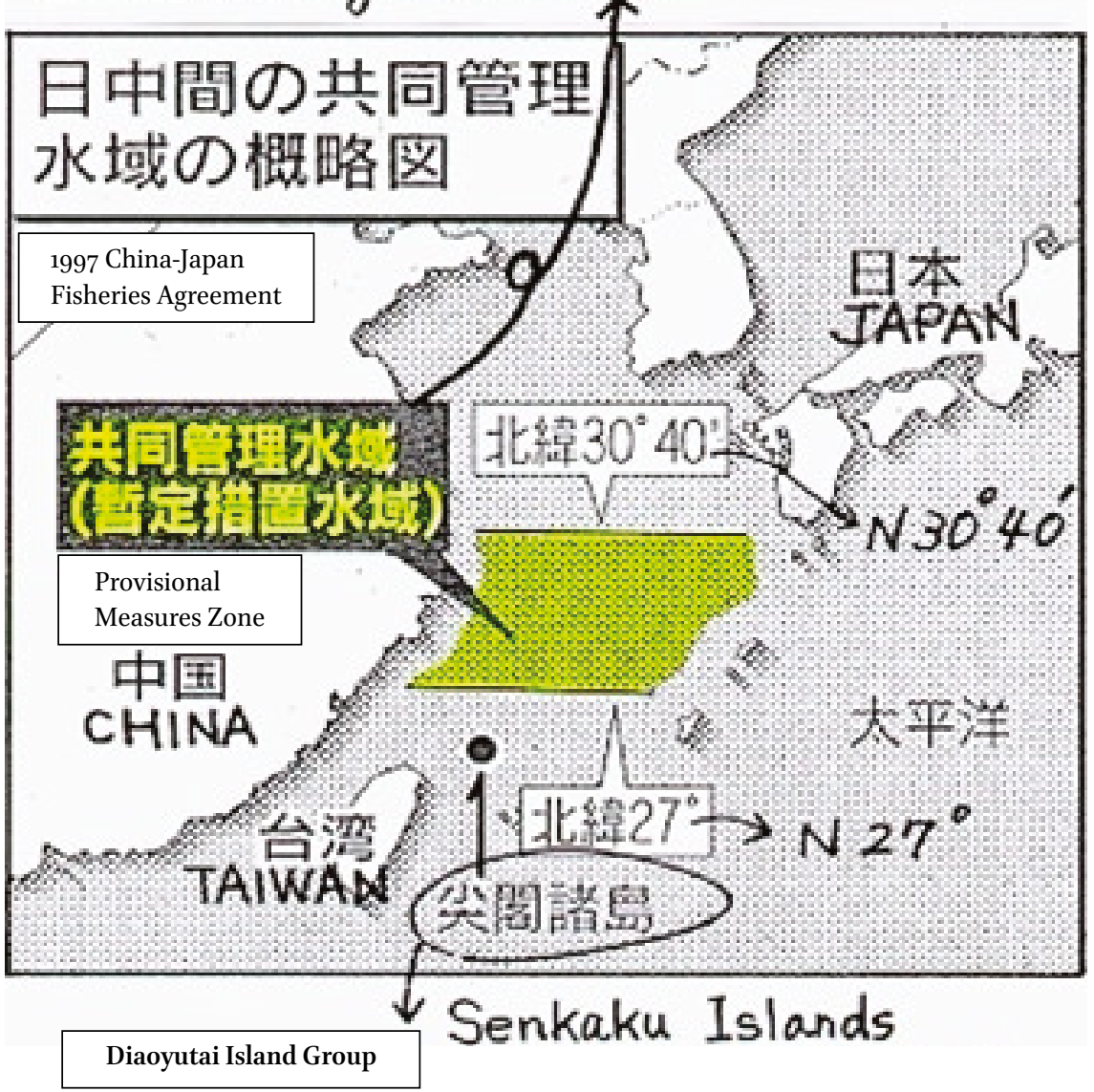

FIgURE 1 The Agreed Provisional Measures Zone under the 1997 Sino-Japanese Fisheries Agreement.

SOURCE: HTTPS://BLOGS.YAHOO.CO.JP/AK08880/52784966.HTML

1. Latitude $27^{\circ}$ North, longitude $126^{\circ} 20^{\prime}$ East

2. Latitude $27^{\circ}$ North, longitude $122^{\circ} 30^{\prime}$ East

3. Latitude $24^{\circ} 46^{\prime}$ North, longitude $122^{\circ} 30^{\prime}$ East

4. Latitude $24^{\circ} 49^{\prime} 37^{\prime \prime}$ North, longitude $122^{\circ} 44^{\prime}$ East

5. Latitude $24^{\circ} 50^{\prime}$ North, longitude $124^{\circ}$ East

6. Latitude $25^{\circ} 19^{\prime}$ North, longitude $124^{\circ} 40^{\prime}$ East

7. Latitude $25^{\circ} 29^{\prime} 45^{\prime \prime}$ North, longitude $125^{\circ} 20^{\prime}$ East

8. Latitude $25^{\circ} 30^{\prime}$ North, longitude $125^{\circ} 30^{\prime}$ East

9. Latitude $25^{\circ} 3^{\prime} 17^{\prime \prime}$ North, longitude $125^{\circ} 30^{\prime}$ East

10. Latitude $25^{\circ} 40^{\prime}$ North, longitude $126^{\circ}$ East 
11. Latitude $26^{\circ} 30^{\prime}$ North, longitude $126^{\circ}$ East

12. Latitude $27^{\circ}$ North, longitude $126^{\circ} 20^{\prime}$ East

In addition, a special cooperation area is also established, which is enclosed by the following points:

1. Latitude $26^{\circ} 30^{\prime}$ North, longitude $126^{\circ}$ East

2. Latitude $26^{\circ} 20^{\prime}$ North, longitude $125^{\circ} 30^{\prime}$ East

3. Latitude $25^{\circ} 3^{\prime} 17^{\prime \prime}$ North, longitude $125^{\circ} 30^{\prime}$ East

4. Latitude $25^{\circ} 40^{\prime}$ North, longitude $126^{\circ}$ East

5. Latitude $26^{\circ} 30^{\prime}$ North, longitude $126^{\circ}$ East

The agreement guarantees the rights of Taiwan fishing vessels in a longdisputed area of overlap between the two countries' claimed EEZs. It opens up a further 4530 square kilometers of ocean within Japan's claimed EEz to Taiwanese fishing vessels. Within the "special cooperation zone," the two sides will cooperate to manage fishery resources. A fisheries commission is establishes to consult on the specific management of the cooperation zone, as well as other matters concerning the area designated by the agreement as a whole. More importantly, under Article 4 of the Agreement, the provisions of the agreement and any measures that adopted in the future for the purpose of implementing the agreement should not be deemed as having any bearing on the position on the law of the sea issues taken by the government agencies of each side that have jurisdiction on the issues.

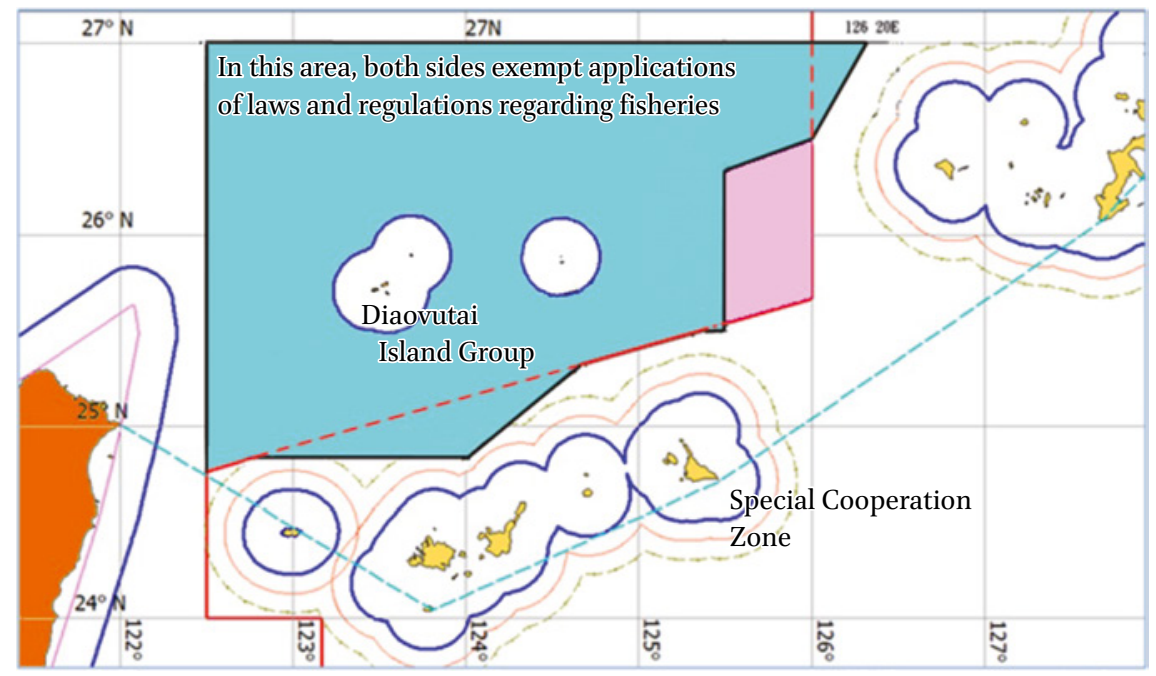

FIgurE 2 The Agreed Zone under the 2003 Taiwan-Japan Fisheries Agreement. sourcE: "The Taiwan-Japan Fisheries Agreement -- Embodying the Ideals and Spirit of the East China Sea Peace Initiative," website of the Roc Ministry of Foreign Affairs at https://www.mofa.gov.tw/Upload/WebArchive/979/The\%2o Taiwan-Japan\%2oFisheries\%2oAgreement\%2o(illustrated\%2opamphlet).PDF 


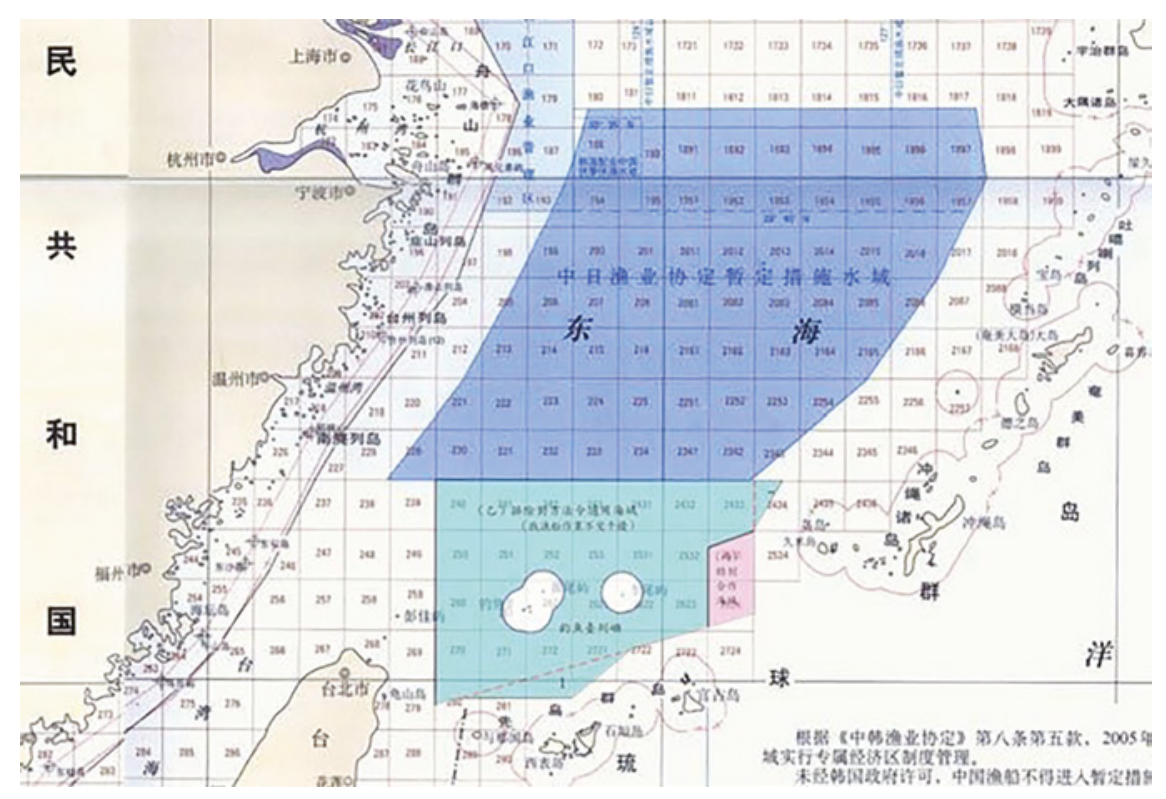

FIgURE 3 The location of the Agreed Zones under the 1997 China-Japan Fisheries Agreement and the 2013 Taiwan-Japan Fisheries Agreement. SOURCE: "TAIWAN-JAPAN FISHERY AGREEMENT SELLING CHINA'S SOVEREIGNTY OVER DIAOYU DAO," APRIL 13, 2013, AVAILABLE AT HTTP:// VIEW.NEWS.QQ.COM/ZT2013/YYXY/INDEX.HTM (IN CHINESE)

IV

\section{Current Status of the Proposals and Agreements and their Implementation}

\section{$1 \quad$ The Japanese and Chinese Peace Proposals}

The call for maritime cooperation between Japan and China and turning the East China Sea into a "sea of peace, cooperation and friendship" continued in the development of Sino-Japanese relations since June 2008 when the two sides signed the Understanding. However, it seems that the efforts have been put on hold by the rising tensions caused by the territorial dispute over the DIG in particular since April 2012.

In December 2011, at the China-Japan summit meeting held in Beijing, the Japanese Prime Minister Yoshihiko Noda expressed "six initiatives" 65 to further

65 These initiatives include: (1) Enhancing Mutual Trust in the Political Area; (2) Promoting the Cooperation for making the East China Sea a "Sea of Peace, Cooperation and Friendship"; (3) Japan-China Cooperation in the Wake of the Great East Japan Earthquake; (4) Grading up of Mutually Beneficial Economic Relations; (5) Promoting Mutual 
deepen diplomatic relations between Japan and China. Among other things, China and Japan shared on a basic recognition that it is becoming more important for them to tackle regional and global issues together as partners for cooperation in accordance with the four basic documents ${ }^{66}$ that govern the China-Japan relations. They also agreed to promote the cooperation for making the East China Sea a "Sea of Peace, Cooperation and Friendship."67 To achieve this goal, they agreed to establish High-Level Consultation on Maritime Affairs" and made an agreement in principle on the text of "Japan-China Maritime Search and Rescue (sAR) Cooperation." In addition, the Prime Minister urged the early resumption of negotiations on the agreement China and Japan singed in June 2008 on resources development in the East China Sea. In response to this request, the Chinese Prime Minister Wen Jiabao stated that the said agreement should be put into action and that China intends to further communication and to work together with Japan. ${ }^{68}$ Japan and China also shared the view that as major countries in the world, they should strengthen dialogues and cooperation concerning regional and global issues. ${ }^{69}$

In May 2012, when attending the Trilateral Summit of Japan, China and the Republic of Korea in Beijing, the Japanese Prime Minister Noda reiterated his "six initiatives" and welcomed the first plenary meeting of "Japan-China HighLevel Consultation on Maritime Affairs" that was held in Hangzhou on May 16, 2012. ${ }^{70}$ Prime Minister Noda and Prime Minister Wen expressed expectations

Understanding between People in Both Countries; and (6) Strengthening Dialogue and Cooperation on Regional and Global Issues. See Japan-People's Republic of China Summit Meeting (Summary), Ministry of Foreign AfFairs of Japan (25 December 2011), available at http://www.mofa.go.jp/region/asia-paci/china/meeting1112.html [hereinafter Summit Meeting Summary].

66 These documents include:The 1972 Joint Communiqué of the Government of Japan and the Government of the People's Republic of China; The 1978 Treaty of Peace and Friendship between Japan and the People's Republic of China; The 1998 Japan-China Joint Declaration on Building a Partnership of Friendship and Cooperation for Peace and Development and The 2008 Sino-Japanese Joint Statement on All-round Promotion of Strategic and Mutually Beneficial Relations.

67 Summit Meeting Summary, supra note 65.

68 Ibid.

69 Liu Weimin, Foreign Ministry Spokesperson, People's Republic of China, Regular Press Conference (14 October 2011), transcript available at http://www.fmprc.gov.cn/eng/ $\mathrm{xwfw} / \mathrm{s} 2510 / 2511 / \mathrm{t} 868322 . \mathrm{htm}$.

70 At the meeting, Japan and China introduced the organizations and activities of their respective maritime-related department as well as ongoing cooperation and exchange programs between the two countries. It was agreed to hold the next meeting in the second half of 2012 in Japan and continue to communicate through diplomatic channels. Both countries agreed to establish the Working Group on "the Policy and the Laws of the Seas." 
that the consultation would lead to enhancing trust between the maritimerelated agencies of the two countries. During the meeting, the two prime ministers expressed their respective position on the status of Diaoyu Dao/Senkaku Islands. Prime Minister Noda said, "it would be undesirable if this issue were to impact adversely on the overall bilateral relations." ${ }^{71} \mathrm{He}$ also indicated that the active maritime activities by the Chinese in the areas surrounding the disputed islands are giving undesirable influence to the sentiment of Japanese people and therefore he urged China to act with restraint. In addition, Prime Minister Noda stressed the importance of maintaining strategic stability among Japan, the United States, and China, and stated in this connection that it was essential for the three countries to promote dialogue among them.

In response, Chinese Prime Minister Wen said that China was seriously considering the trilateral dialogue. ${ }^{72}$ In July 2012, the Japanese Foreign Minister Koichiro Gemba and Chinese Foreign Minister Yang Jiechi met in Phnom Penh, Cambodia on the sidelines of the ASEAN-related Ministers' Meeting. Among other things, they talked about the disputed DIG by repeating their respective basic stand on the issue. They also agreed to promote more cooperation and dialogue. The Japanese Foreign Minister Gemba strongly requested for the early resumption of negotiations for the China-Japan agreement regarding the development of natural resources in the East China Sea. He also stated that the Japanese side hoped for the early start of the Japan-US-China dialogue. China's Foreign Minister Yang responded by stating that China's

The Japanese side explained about the development of making the domestic laws based on the Basic Act on Ocean Policy and the Basic Plan on Ocean Policy as well as Japan's efforts in the fields of laws of sea in terms with the promoting rule of law in the international society. The Chinese side introduced their views and policies on the maritime policies and the laws of sea. Due to the diplomatic standoff between the two countries escalated on September 11 after the Noda administration finalized the purchase of the disputed Diaoyu Dao/Senkaku Islands, the second round of the "Japan-China High-Level Consultation on Maritime Affairs" was not held during the second half of 2012. However, a Track II international conference entitled "Northeast Asian Cooperation and Integration: Constructing a Peaceful Security Environment in Northeast Asia: Towards an Understanding of the Interplay of Cultural and Material Forces" was organized by Zhejiang University and The Korea Foundation for Advanced Studies ("KFAs"), which was held in Hangzhou, China on 14-15 December 2012. For more information about the first meeting, see Ministry of Foreign Affairs of Japan, The First Round Meeting of Japan-China High Level Consultation on Maritime Affairs (Outline) (16 May 2012), available at http://www.mofa. go.jp/policy/maritime/jchlc_maritimeo1.html.

71 Prime Minister of Japan and His Cabinet, Japan-People's Republic of China Summit Meeting (Summary) (31 May 2012), available at http://www.kantei.go.jp/foreign/noda/ diplomatic/201205/3ijck_e.html. 
position on implementing a principle agreement concerning the East China Sea remained unchanged, and that he would like to continue working-level communications. ${ }^{73}$

In November 2012, the government of Japan expressed its intention to strengthen cooperation with China and continue to make efforts to make East China Sea a "sea of peace, cooperation and friendship" by promoting understanding and trust between the maritime authorities of the two countries through the Japan-China High-Level Consultation on Maritime Affairs" under the "Six Initiatives" that were agreed between the two countries. ${ }^{74}$

As tensions continue to rise in the area near the disputed DIG, it has become more important for China and Japan to make efforts to make East China Sea a "sea of peace, cooperation and friendship" by proposing peaceful measures and establishing dialogue and conflict management mechanisms.

\section{$2 \quad$ The 1997 China-Japan Fisheries Agreement}

The China-Japan Fisheries Agreement has been implemented successfully since its entry into force on 1 June 2000. In addition to the China-Japan Fisheries Joint Committee, a group of experts on marine living resources and law enforcement dialogue mechanism were also established to help implement the agreement. In August 2007, China Fisheries Association and Japan Fisheries Association signed a Protocol on Safety of Fisheries Operation. During the period of time between 2000 and 2009, 5,000 Chinese fishing vessels applied for operation in the Japanese EEZ in accordance with the Agreement. During the same period of time, 494 patrolling missions, with a total of 4941 patrolling days, were conducted by the Chinese fishery agency in the contracting waters. ${ }^{75}$

In April 2012, the 13th China-Japan Fisheries Joint Committee was held in Tokyo, where the two sides reviewed the implementation status of the Fisheries Agreement, discussed the conditions for fishery operations in each side's $\mathrm{EEZ}$, and decided the number of fishing vessels that were allowed to fish in each side's EEZ and the Provisional Measures Zone, as well as the allowable catch. It was agreed that between 1 January to 31 May 2012, Japan allowed 288 Chinese fishing trawlers to fish in its EEZ, with a total catch no more than 2389 tons. Between 1 June 2012 to 31 May 2013, Japan allowed 288 Chinese trawlers

73 Ministry of Foreign Affairs of Japan, Japan-China Foreign Ministers' Meeting (Overview) (11 July 2012), available at http://www.mofa.go.jp/region/asia-paci/china/meeting1207_ fm.html.

74 Fact Sheet on the Senkaku Islands, Ministry of Foreign Affairs of Japan, November 2012, available at http://www.mofa.go.jp/region/asia-paci/senkaku/fact_sheet.html.

75 Ten Years'Implementation of the China-Japan Fisheries Agreement, CHInA Fis he ry News, 8 June 2010, available at http://www.farmer.com,cn/wlb/yyb/yy2/201006o8019o.htm. 
to fish in Japan's EEZ, with a total catch no more than 5,733 tones, and 55 squid fishing boats with a total catch no more than 4,141 tons. China allowed 111 Japanese purse seine fishing vessels to enter into China's EEz to fish, with a total catch no more than 8,558 tons, and 26 trawlers to fish with a total catch no more than 621 tons. Within the Provisional Measures Zone, China agreed to control its total number of fishing vessels at 18214, with fishing effort target set at $1,703,160$ tons. Japan agreed to control its total number of fishing vessels at 800 , with fishing effort target set at 109,250 tons. The two sides also discussed the joint study of large jelly fish, the use of special fishing purse seine nets, protection of eel larvae, and other fisheries cooperation matters. ${ }^{76}$

In May 2013, Okinawa Vice Governor Kurayoshi Takara and the members of the Okinawa Federations of Fisheries Cooperatives and the Ikema Fisheries Cooperatives asked Senior Vice Minister of Agriculture, Forestry and Fisheries, Taku Eto to review the 1997 Japan-China Fisheries Agreement. The fishermen said the Japanese and Chinese governments concluded this pact in 1997 without any explanation to the local people before it went into effect in 2000. They suggested that the agreement has led to overfishing of coral reefs and has devastated the habitat of bottom fish. Accordingly, they asked for the government to review the pact by working with China at the Joint Fisheries Committee meeting to be held June $2013 .{ }^{77}$ In addition, since the 1997 Japan-China Fisheries Agreement did not cover the area of water below 27 degrees north latitude, Okinawa Vice Governor Kurayoshi Takara and the members of the Okinawa Federations of Fisheries Cooperatives and the Ikema Fisheries Cooperatives asked the Japanese government to resolve three issues: (1) Rescinding the content of the Foreign Minister's letter ${ }^{78}$ and regulating the Chinese fishing boats working within the area of water (2) Creating a system to prevent net fishing on coral reefs; and (3) Review the area of water included in the Japan-Taiwan fishing pact. ${ }^{79}$

As tensions continue between China and Japan in the waters near the DIG, in particular, the respective claimed 12-nm territorial waters surrounding

$7^{6} \quad$ The 13th China-Japan Fisheries Joint Committee was held in Tokyo, 3 May 2012, available at http://www.shennong.com/n/1/25/121402.shtml, and http://www/fishzf.com/article. asp?artid=141292 and http://www.jfa.maff.go.jp/j/press/kokusai/120420.htnl.

77 Okinawan fisheries groups ask government to review Japan-China fisheries pact, RYU KYU SHIMPO, 30 May 2013, available at http://english.ryukyushimpo.jp/2013/06/05/10488/.

78 In the letter sent by the Foreign Minister of Japan to his counterpart of China in November 1997, Japan agreed that it would not apply the relevant fisheries laws to Chinese fishing boats in that area of water below 27 degrees north latitude.

79 Okinawan fisheries groups ask government to review Japan-China fisheries pact, RYUKYU SHIM PO, 30 May 2013, available at http://english.ryukyushimpo.jp/2013/o6/05/10488/. 
the disputes islands, and as a result of signing the Taiwan-Japan Fisheries Agreement on 10 April 2013, it can be expected to see the rise of fisheries management conflicts in the area of water below 27 degrees north latitude in the near future (See Figure 3).

\section{The EcsPI and Taiwan-Japan Fisheries Agreement}

The East China Sea Peace Initiative, proposed in August 2012, has gradually gained support from the international community for its contributions to reducing tensions and maintaining regional stability. In September 2012, for example, Eduard Kukan, a Member of the Foreign Affairs Committee, the European Parliament stated that

The East China Sea Peace Initiative was proposed to promote regional peace and security, and as such is in line with the EU's East Asia Guidelines and EU Common Foreign and Security Policy (CFSP) which encourage peaceful and cooperative solutions to disputes. All parties concerned should take this initiative into consideration with a view to bringing about peaceful and positive developments. ${ }^{80}$

In March 2013, the European Parliament passed a report on EU-China Relations, in which it "takes note of Taiwan's [East China Sea Peace] initiative with a view to reaching a consensus on a code of conduct for the East China Sea and the establishment of a mechanism allowing all sides to cooperate in the joint exploitation of the region's natural resources, including capacity for the generation of electricity from renewable sources." ${ }^{81}$

Although the government of Japan does not consider the DIG issue a "dispute," it accepts the spirit, principles and proposals that are laid out in Taiwan's peace initiative. It seems that what Japan opposes is a three-way dealing with the territorial issue. It also does not like to see the China-Taiwan cooperation on the DIG issue in the East China Sea. On 6 June 2013, Japan's Chief Cabinet Secretary Yoshihide Suga rejected President Ma's call for a three-way dialogue with China and Japan on fishery rights and natural resources in the East China Sea, but he added, “We haven't changed our stance that Japan will promote concrete cooperation with neighboring countries and regions to ensure peace

8o East China Sea Peace Initiative positive step to reassuring peace and dialogue for consensus in the region, Press Release, epp Group in the European Parliament, 20 September 2012, available at http://www.eppgroup.eu/press-release/East-China-Sea -Peace-Initiative-positive.

81 European Parliament resolution of 14 March 2013 on EU-China relations, 2012/2137 (INI), available at http://www.europarl.europa.eu/sides/getDoc.do?type=TA\&language=EN\&re ference $=\mathrm{P}_{7}-\mathrm{TA}-2013-97$, para. 49 . 
and security in the East China Sea." ${ }^{22}$ The signing of the Japan-Taiwan fisheries agreement is considered one of the positive responses of Japan to the ECSPI ${ }^{83}$

On 7 May 2013, Taiwan and Japan established a bilateral fishing commission, which serves as an institutionalized negotiation mechanism for future talks of fisheries cooperation. Taiwan members of the commission include Chang Jen-joe, senior counselor with the Association of East Asian Relations; James Sha, director-general of the Fisheries Agency; officials from the Roc Coast Guard Administration and Ministry of Foreign Affairs; and representatives from local fishermen's associations. Japanese members include Michihiko Komatsu, director-general of Tokyo-based Interchange Association's General Affairs Department; Kenichi Okada, secretary-general of the IA's Taipei Office; officials from Japan's foreign ministry, coast guard and fisheries agencies; and representatives of an Okinawa fishing committee. ${ }^{84}$ During the first session of Taiwan-Japan Fishing Commission, the two sides agreed to complete revising respective laws enabling the Taiwan-Japan fishery agreement to take effect 10 May 2013 and continue negotiations on fishing issues with commission meetings scheduled at least once a year.

Both sides agreed to temporarily shelve the sovereignty dispute over the DIG and designated the area between $27^{\circ}$ north latitude and Japan's Sakishima Islands as waters where fishing by both Taiwan and Japan vessels would be allowed to operate. Most fishermen welcomed the conclusion of the agreement. The agreement expands the fishing grounds of Taiwanese fishermen by an additional 4,530 square kilometers beyond the so-called "temporary enforcement line." The second meeting was held in July 2013. It was reported that Taiwan catches of yellow fin tuna in waters off northeastern Taiwan have increased $20 \%$ in May 2013 compared with the same period last year following the signing of the Taiwan-Japan Fisheries Agreement. ${ }^{85}$

The signing of Taiwan-Japan Fisheries Agreement has received positive responses from the international community, including the US Department of State. On 23 April 2013, for example, Raymond Burghardt, the chairman of the American Institute in Taiwan (AIT), stated that Taiwan and Japan have

82 Joseph Yeh, Tokyo rejects Diaoyutai talks; MOFA reiterates sovereignty, CHInA Post, 8 June 2013, available at http://www.chinapost.com.tw/taiwan/foreign-affairs/2013/06/o8/ 380627/Tokyo-rejects.htm.

83 Kawashima Shin, The Implications for the Japan-Taiwan Fisheries Agreement, NipPon. сом, 5 June 2013, available at http://www.nippon.com/en/currents/dooo81/.

84 Taiwan, Japan set up joint fishing commission, TAIWAN TODAY, 8 May 2013, available at http://taiwantoday.tw/ct.asp?xitem $=204842 \&$ CtNode $=414$.

85 Catches rise since Japan fisheries agreement inked, TAIPEI TIM Es, 26 May 2013, available at http://www.taipeitimes.com/News/taiwan/archives/2013/05/26/2003563216. 
"well-handled" the fishing rights dispute surrounding the DIG in the East China Sea. He said the agreement "really mapped the interest of both sides in a rather neat way." ${ }^{86}$ American scholars such as Douglas Paal, Randall Schriver, Richard Bush, and Bonnie Glaser are also in support of the move and consider a good example of dispute resolution. ${ }^{87} \mathrm{On} 10$ June 2013, a resolution was proposed in the US Senate, in which the Taiwan-Japan fisheries agreement was considered a model for administering fishing resources in the overlapping EEzs in the East China Sea. ${ }^{8} 8$

The East China Sea Peace Initiative, proposed in August 2012, has gradually gained support from the international community for its contributions to reducing tensions and maintaining regional stability. Although official reactions from Japan and China, the parties directly involved in the territorial dispute over the DIG and surrounding waters, are not straightforward, there has been seen positive responses from the two parties, in particular, after the signing of the Taiwan-Japan Fisheries Agreement on 10 April 2013.

In addition to the positive responses from Japan and the United States to both the ECSPI and the Taiwan-Japan Fisheries Agreement, it seems that China is also moving toward the direction of supporting the initiative. In May 2013, President Ma stated that Taiwan is willing to talk with China about the possibility of signing a bilateral fisheries agreement to help govern fishing activities in waters around the DIG. ${ }^{89}$ On 6 June 2013, President Ma said that since there are also fisheries matters between Taiwan and China that need to be settled, Taiwan does not rule out the possibility of signing a fisheries agreement, similar to the one between Taiwan and Japan, to establish a joint fishery conservation and management zone in the East China Sea. In addition, he stressed, just like the 18 agreements that have been signed so far between Taiwan and China, this fisheries agreement can be signed, not between two countries, but under

86 Taiwan, Japan fishing rights issue 'handled well': AIT chairman, TAIWAN NEws, 24 April 2013, available at http://www.taiwannews.com.tw/etn/news_content.php?id=2204521.

87 Taiwan-Japan fishery pact good example of dispute resolution: expert, Focus TaIWAN, 16 April 2013, available at http://taiwandiaoyutaiislands.tw/EN/Interview_Detail. aspx?ID=1373. Assessing Taiwanese President Ma's Message to America, CARnegie EnDowment For International Peace, 16 April 2013, available at http://m.ceip. org/2013/04/16/assessing-taiwanese-president-ma-s-message-to-america/fyzm.

88 S. Res. 167 , Reaffirming the strong support of the United States for the peaceful resolution of territorial, sovereignty, and jurisdictional disputes in the Asia-Pacific maritime domains, 10 June 2013, available at http://thomas.loc.gov/cgi-bin/query/z?c113:S.ees.167.

89 Ma: Taiwan and Japan sign fisheries agreement, welcome China to Join, CHinA Times, 9 May 2013, available at http://news.chinatimes.com/mainland/11050506/112013050900173. html (in Chinese). 
special cross-Strait relations. ${ }^{90}$ In response, Fan Liqing, the spokeswoman of Taiwan Affairs Office of the State Council stated that the two sides can further study the matter concerning fisheries cooperation..$^{91}$

\section{v The Challenges China, Japan, and Taiwan Are Facing}

The development and implementation of the peaceful proposals and agreements on maritime cooperation have encountered a number of challenges. One of the biggest challenges concerns the Japanese position that Tokyo does not have any territorial dispute to be solved over the DIG, and that the leaders of China and Japan did not reach consensus on putting aside the DIG issue in 1972 on the occasion of the normalization of China-Japan diplomatic relations.

On 2 June 2013, Lieutenant General Qi Jianguo, deputy chief of the general staff of the PLA, stated at the Shangri-La Defense Dialogue in Singapore that, "We should put aside disputes, work in the same direction and seek solutions through dialogue and coordination, particularly when it comes to disputes concerning sovereignty as well as maritime rights and interests." ${ }^{\prime 2}$ In response, Japanese Chief Cabinet Secretary Yoshihide Suga said on 3 June 2013 that there are no disputes involved with the DIG. He also dismissed the existence of bilateral consensus to put the islands dispute aside. ${ }^{93}$ Although the Japanese government has maintained that Tokyo is willing to work with Beijing to prevent individual issues from undermining overall relations from the viewpoint of "Mutual Beneficial Relationship Based on Common Strategic Interests" and "Japan always keeps the door to dialogue open," ${ }^{44}$ as long as Tokyo continues to insist on its current position on the DIG, it is unlikely for the two countries to move forward to make the East China Sea a "sea of peace, friendship, and

9o President: Does not rule out signing a fishery agreement with Mainland China, CENTRAL News Agency, 6 June 2013, available at http://www.cna.com.tw/News/arpL/2013 o6o6o432-1.aspx.

91 Taiwan Affairs Office's Response to A Reporter's Question Concerning Ma Ying-jeou's Proposal to sign a Cross-Strait Fishery Pact, 9 June 2013, available at Http://roll.sohu. $\mathrm{com} / 20130609 / \mathrm{n} 378506284$.shtml.

92 China proposes putting aside Asian maritime disputes, The MAINICHI, 3 June 2013, available at http://mainichi.jp/english/english/newsselect/news/20130603p2goomodmo410 ooc.html.

93 Japan politicians seek to mend ties, China Daily, June 4, 2013, available at http://usa.chinadaily.com.cn/china/2013-06/04/content_16562495.htm.

94 See, Speech by H.E. Mr. Fumio Kishida, Minister for Foreign Affairs of Japan, at the 19th International Conference on "The Future of Asia," Imperial Hotel, Tokyo, Japan, 23 May 2013, available at http://www.mofa.go.jp/page3e_oooo57.html. 
cooperation" as they agreed before. It is also unlikely for them to resume talks on joint development of oil and gas resources in the East China Sea in accordance with the 2008 Understanding.

Another challenge for the development and implementation of the peaceful proposals and agreements on maritime cooperation in the East China Sea concerns the sensitive "one China" issue. Both China and Japan have been very careful in responding to President Ma's East China Sea Peace Initiative.

On 12 April 2013, two days after signing the fisheries agreement between Taiwan and Japan, the spokesperson of China's Foreign Ministry, Hon Lei, stated at a regular press conference that "China opposes Japan's unilateral actions in relevant waters and urges Japan to properly deal with Taiwan-related issues in strict accordance with the principles and spirit of the China-Japan Joint Statement." ${ }^{\prime 5}$ It is clear that China is concerned about a possible revival of Taiwan's diplomatic status and its political relations with Japan. At the same time, China considers the Beijing government the authoritative defender of Chinese sovereignty over the DIG and Taiwan should work together with China in safe-guarding the islands and relevant maritime rights and interests. Fan Liqing, a spokeswoman for the Taiwan Affairs of the State Council, also urged that "It is the duty across the Straits to ensure the fishing rights and interest of fishermen from both sides (to operate) in this traditional fishery area on the basis of safeguarding territorial sovereignty."96

Japan considered the agreement it signed with Taiwan as a private sector fisheries arrangement, instead of a government-to-government agreement between Tokyo and Taipei. On 18 April 2013, in response to a question concerning the Japan-Taiwan Fisheries Agreement, Japanese Assistant Press Secretary Masaru Sato stated that

This Japan-Taiwan private sector fisheries arrangement was signed April 10, and negotiations had been held between private bodies of Japan and Taiwan.... the two private authorities have been negotiating over the fisheries issue for many years since $1996, \ldots$ But it was postponed sometime in 2009, but after the situation concerning the Senkaku Islands intensified since last September, we resumed discussions. And this time the Fishery Arrangement was successfully made. Although we have not changed our policy in any way regarding the treatment of Taiwan vis-à-vis China, the

95 Foreign Ministry Spokesperson Hong Lei's Regular Press Conference on 12 April 2013, 13 April 2013, website of the PRC Foreign Ministry, available at http://www.fmprc.gov.cn/eng/ $\mathrm{xwfw} / \mathrm{s} 2510 /$ t1031012.shtml.

96 Japan-Taiwan fishery agreement raises 'concern,' ChInA DAILY, 11 April 2013, available at http://www.chinadaily.com.cn/china/2013-04/11/content_16391602.htm. 
Japanese Government welcomed the signing as the non-governmental working relations between Taiwan and Japan bearing fruit. So it is hoped this will have a positive impact even on the situation concerning the Senkaku Islands. ${ }^{97}$

On 1 June 2013, at the Shangri-La Dialogue in Singapore, the Japanese Minister Itsunori Onodera reiterated the Japanese position on the legal nature of Taiwan-Japan Fisheries agreement. He said, it is a private sector agreement with Taiwan. But he added, the signing of the agreement "is a benefit for the fisherman and the economies of both countries and that this is progress." 98

In February 2013, President Ma gave reasons to explain why Taipei decides not to collaborate with Beijing on the DIG issue. First, he said, because China has never recognized the legitimacy of the Peace Treaty signed between Taiwan and Japan in 1952. Second, the Chinese government has not responded to Taiwan's East China Sea Peace Initiative. And finally, Beijing hoped the sovereignty issue would be kept out of the fishery talks between Taipei and Tokyo. ${ }^{99}$ Unless a flexible arrangement between China and Taiwan can be made, it is unlikely for Taipei to be included in any of the future bilateral negotiations between China and Japan for law enforcement mechanisms or agreements on maritime cooperation in the East China Sea. It is also unlikely to see a threeway talk between China, Japan, and Taiwan.

A third challenge is the potential conflicts in the territorial waters $12 \mathrm{~nm}$ measured from the baselines of the DIG that are claimed respectively by China, Japan, and Taiwan. If no agreements can be reached between the three parties in the near future, this body of waters and the air above it will become the site of accidental conflicts between China and Japan as well as between Japan and Taiwan. The chance for conflicts will be bigger between China and Japan, since activists from Japan and from Hong Kong, Macau, and Mainland China will continue to take actions for the purpose of safeguarding sovereignty over the DIG. Actually it happened twice since the signing of Japan-Taiwan Fisheries Agreement. In April and May 2013, respectively, the Japanese activists and fishermen, guarded by the Japanese coast guard vessels, sailed to the waters near the DIG. In response, China dispatched maritime surveillance vessels to expel

97 Press Conference by Assistant Press Secretary Masaru Sato, 18 April 2013, available at http:// www.mofa.go.jp/press/kaiken/kaiken6e_ooooo5.html.

98 Defending National Interests; Preventing Conflict: Q\&A, 1 June 2013, available at http://www .iiss.org/en/events/shangri\%2ola\%2odialogue/archive/shangri-la-dialogue-2013-c89o/ second-plenary-session-8bc4/qa-1497.

99 Chris Wang, Isle dispute a test of Ma's China policy, TAipei Times, 20 February 2013, available at http://www.taipeitimes.com/News/taiwan/archives/2013/o2/20/2003555248. 
the Japanese intruders. The possibility for Chinese Taiwanese vessels to enter the $12 \mathrm{~nm}$ zone surrounding the DIG cannot be ruled out.

A fourth challenge is the increasing call from Japanese fishermen to review the 1997 Japan-China Fisheries Agreement and the 2013 Taiwan-Japan Fisheries Agreement. Okinawa fishermen asked the Japanese government to review the fisheries agreement with China because the agreement has led to overfishing of coral reefsand has devastated the habitat of bottom fish. ${ }^{100}$ In addition, they complained that the Japanese government failed to take their interests into account as Taiwanese trawlers are given more waters to operate in the maritime zones established under the April 2013 Japan-Taiwan Fisheries Agreement. Okinawa fishermen stated that competition with Taiwanese fishing vessels will intensify and good fishing areas for them will shrink as a result. ${ }^{101}$ However, Taiwanese fishermen stated that Japanese authorities are implementing the agreement "too strictly" and they would like to see a buffer zone set up immediately outside the maritime zones covered by the Japan-Taiwan Fisheries Agreement. ${ }^{102}$

A fifth challenge is related to the demand from the Chinese fishermen for the right to operate in the maritime zones covered by the Taiwan-Japan Fisheries Agreement and the demand from the Taiwanese fishermen for the right to operate in the provisional measures zone established by the 1997 ChinaJapan Fisheries Agreement (See Figure 3). This requires cross-Strait negotiations under the ECSPI. In addition, it will be necessary for Japan, Taiwan, and China to enter into trilateral talks that aim to combine the two existing fisheries agreements and come to an agreement for a new agreement between the three parties. In order to avoid the rise of the "one-China" issue, a flexible arrangement similar to the Commission for the Conservation of Southern Bluefin Tuna (ссSвт) or the Western and Central Pacific Fisheries Commission (WCPFC) can be made so to allow "Fishing Entity of Taiwan" become a member of the Extended Commission of the сслвт or a member of the Western and Central Pacific Fisheries Commission as Chinese Taipei. Alternatively, a fisheries agreement can be signed between China Fisheries Association, ${ }^{103}$ Japan Fisheries Association, ${ }^{104}$ and Taiwan's National Fishermen's Association. ${ }^{105}$

100 Okinawa fisheries groups ask government to review Japan-China fisheries pact, RYU KU SHIмPO, 30 May 2013, available at http://english.ryukushimpo.jp/2013/06/05/10488/.

101 Okinawa fishermen protest to the Government over agreement with Taiwan on fishing rights, RYU KU SIM PO,13 April 2013, available at http://english.ryukushimpo.jp/2013/04/20/10039/. See also, Japan-Taiwan fisheries pact leaves fishermen on both sides dissatisfied, Kyoto News, June 10, 2013, available at http://english.kyodonews.jp/news/2013/o6/229573.html

102 Japan-Taiwan fisheries pact leaves fishermen on both sides dissatisfied, ibid.

103 Available at http://www.china-cfa.org/.

104 Available at http://www.suisankai.or.jp/index_e.html.

105 Available at http://www.tpfae.org.tw. 


\section{Concluding Remarks}

Maritime cooperation between China, Japan, and Taiwan is possible in the areas of conservation and management of fisheries resources as well as exploration and exploitation of oil and gas resources in the East China Sea, including the area surrounding the Diaoyutai/Senkau Islands. Possible non-government organizations for fisheries cooperation include China Fisheries Association, Japan Fisheries Association, and Taiwan's National Fishermen's Association. Possible non-government organizations for oil and gas exploration and exploitation include China National Offshore Oil Corporation (CNOOC), Japan Oil, Gas and Metals National Corporation (JOGMEC), ${ }^{106}$ and Taiwan's CPC Corporation. ${ }^{107}$

Maritime cooperation between and/or among the three parties have the potential not only to help govern the activities that are related to exploration, exploitation, preservation, or protection of the living and non-living resources of the East China Sea, but also to manage the conflicts that arise from the sovereignty and maritime disputes over the DIG. Unfortunately there has been seen a lack of political willingness, in particular, from the PRC and Japanese governments, to promote maritime cooperation so that the East China Sea can be transformed into "a sea of peace, friendship and cooperation." Apparently, more efforts need to be taken by the leaders of China, Japan, and Taiwan.

106 Available at http://www.jogmec.go.jp/english/index.html.

107 Available at http://www.cpc.com.tw/english/home/index.asp. 